\title{
RUSSIAN AND EAST EUROPEAN STUDIES
}

Charles Jelavich, Tsarist Russia and Balkan Nationalism. Russian Influence in the Internal Affairs of Bulgaria and Serbia, 1879-1886

Nicholas V. Riasanovsky, Nicholas I and Official Nationality in Russia, 1825-1855

Richard A. Pierce, Russian Central Asia, 1867-1917. A Study in Colonial Rule

Gregory Grossman, ed., Value and Plan: Economic Calculation and Organization in Eastern Europe

Charles and Barbara Jelavich, eds., The Education of a Russian Statesman. The Memoirs of Nicholas Karlovich Giers

Jerzy F. KarCZ, ed., Soviet and East European Agriculture

Alan A. Brown and Egon Neuberger, International Trade and Central Planning 
